\title{
Rancang Bangun Game Manik Angkeran Berbasis Android Pada Tahap Level Poin Pertama
}

\author{
I Dewa Gede Agung Pandawana*1, I Nyoman Agus Suarya Putra ${ }^{2}$, I Made Marthana Yusa ${ }^{3}$ \\ ${ }^{1,2,3}$ Program Studi Teknik Informatika, STMIK STIKOM Indonesia, Bali, Indonesia \\ e-mail: *1. pandawana@unmas.ac.id, ${ }^{2}$ nyomansuarya@ stiki-indonesia.ac.id, \\ 33ade.marthana@stiki-indonesia.ac.id
}

\begin{abstract}
Abstrak
Abstrak; Penelitian ini merupakan tahapan selanjutnya dari penelitian sebelumnya yang berjudul Perancangan Pengembangan Tokoh Manik Angkeran Untuk Media Game Interaktif Cerita Terpisahnya Jawa Dan Bali Berbasis Android. Permasalahan dimana seiring berkembangnya zaman dan teknologi, cerita rakyat mulai dilupakan. Untuk menarik minat anak-anak, maka dibuatlah media game interkatif cerita rakyat ini berbasis Android. Pada penelitian sebelumnya, dilakukan perancangan terhadap seluruh karakter dari game Manik Angkeran. Sedangkan pada penelitian tahap lanjut ini, akan dirancang dan dibangun level per level dari Game Manik Angkeran. Dimana pada masing-masing level permainan, karakter Manik Angkeran akan menghadapi raksasa yang berbeda. Manik Angkeran harus mengalahkan para raksasa agar dapat melanjutkan ke level selanjutnya. Pada setiap kali melawan raksasa, Manik Angkeran akan mendapatkan koin emas (pis bolong mas). Dimana nantinya, koin-koin ini dapat digunakan untuk membeli bahan bangunan, yang akan digunakan untuk membangun asrama (pesraman). Tujuan akhir dari game ini adalah pertempuran tokoh Manik Angkeran untuk mendapatkan emas Naga Basukih. Para Raksasa lawan dari Manik Angkeran ini diambil dari simbol-simbol dalam semiotika gambar yang memberi kesan tentang psikologi kehidupan manusia yang meliputi, keserakahan (Babi), ketamakan dan kemarahan (Raksasa). Dalam level game ini, yang ingin disampaikan adalah bahwa yang terkait keserakahan, ketamakan dan keegoisan dapat dengan mudah terkalahkan.
\end{abstract}

Kata kunci-Rancang bangun, Level, Game, Manik Angkeran, Android

\begin{abstract}
Abstract: This research is the next stage of the previous research entitled Development of the Awakening Bead Figure for Interactive Game Media The Story of the Separation of Java and Bali Based on Android. A problem where as the times and technology develop, folklore begins to be forgotten. To attract children's interest, an interactive folklore game media was made based on Android. In previous studies, the design of all characters from Manik Angkeran was carried out. Whereas in this advanced research, it will be designed and built level by level from Manik Angkeran Game. Where at each level of the game, Manik Angkeran characters will face different giants. Manik Angkeran must defeat the giants in order to proceed to the next level. Every time you fight a giant, Manik Angkeran will get a gold coin (pis bolong mas). Where later, these coins can be used to buy building materials, which will be used to build a dormitory (pesraman). The final goal of this game is to battle the figure of Manik Angkeran to get the golden Dragon Basukih. The opposing giants of Manik Angkeran are taken from the symbols in the semiotics of images which give an impression of the psychology of human life which includes, greed (Pig), greed and anger (Giant). At the level of this game, what I want to say is that things related to greed, greed and selfishness can be easily defeated
\end{abstract}

Keywords—Design, Level, Game, Manik Angkeran, Android

Received October 25 ${ }^{\text {th }}, 2019 ;$ Revised November 21 ${ }^{\text {th }}, 2019 ;$ Accepted Desember $20^{\text {th }}, 2019$ 


\section{PENDAHULUAN}

Pada zaman dahulu cerita rakyat sering diceritakan oleh orang tua kepada anaknya disaat menjelang tidur. Imajinasi seorang anak berkembang ketika mendengar sebuah cerita. Anak-anak akan membayangkan tokoh, tempat, dan seperti apa peristiwa terjadi. Hal ini mampu meningkatkan imajinasi dan rasa ingin tahu anak. Namun dengan semakin berkembangnya zaman dan teknologi cerita rakyat mulai dilupakan. Cerita yang biasanya diceritakan oleh orang tua kepada anaknya mulai tergantikan oleh media telivisi, dan gadget. Dengan kata lain tayangan pada media televisi, dan gadget pada zaman sekarang sangat mempengaruhi pemikiran dan pola pikir anak-anak dibawah umur namun seperti yang kita ketahui tayangan-tayangan yang ada di televisi hampir tidak ada yang mencerminkan nilai-nilai positif, rata-rata semua hanya mempertontonkan hal-hal yang bersifat hiburan semata. Dengan tayangan yang kurang mendidik tersebut, pola fikir serta tingkah laku anak-anak di zaman sekarang menjadi berubah dan kurang memiliki nilai-nilai moral, nilai kesopanan, serta rasa cinta terhadap bahasa sendiri. Hal tersebut dapat dibuktikan dari artikel-artikel yang membahas mengenai perilaku anak-anak dibawah umur yang semakin menyimpang dari hal-hal positif (Pandawana, 2017) Dari uraian pengembangan penelitian sebelumnya dari perancangan game Manik Angkeran yang berjudul

Perancangan Pengembangan Tokoh Manik Angkeran Untuk Media Game Interaktif Cerita terpisahnya Jawa dan Bali berbasis Android diperoleh kesimpulan bahwa perancangan pengembangan tokoh Manik Angkeran untuk media game interaktif cerita terpisahnya Jawa dan Bali berbasis android ini telah berhasil dilakukan dengan menggunakan Bahasa Pemrograman LUA. Serta berdasarkan hasil pengujian, seluruh fungsionalitas dari aplikasi telah berjalan dengan baik, ketajaman tampilan gambar pada perangkat handphone yang digunakan untuk pengujian sesuai dengan yang diharapkan. Hanya saja, pengaruh spesifikasi perangkat sangat mempengaruhi performa dari aplikasi. Semakin tinggi spesifikasi dari perangkat handphone, maka semakin baik pula tampilan serta kecepatan dari perangkat untuk membuat dan menampilkan gambar berukuran besar dengan jumlah banyak secara sekaligus. Dengan demikian maka perancangan dapat dikategorikan berhasil serta dapat dikembangkan dalam level berikutnya.

Pada perancangan berikutnya akan dirancang level per level dari Game Manik Angkeran. Poin dari game ini adalah pertempuran tokoh Manik Angkeran untuk mendapatkan emas Naga Basukih. Sang lawan dari Manik Angkeran ini diambil dari simbol-simbol dalam semiotika gambar yang memberi kesan tentang psikologi kehidupan manusia yang meliputi, keserakahan (Babi), ketamakan dan kemarahan (Raksasa). Dalam level game ini, yang ingin disampaikan adalah bahwa hal hal yang terkait keserakahan, ketamakan dan keegoisan dapat dengan mudah terkalahkan. Berdasarkan uraian latar belakang di atas, maka penelitian yang merupakan pengembangan dari penelitian sebelumnya akan dirancang dengan memperhatikan informasi yang dapat memberi dampak yang baik bagi peningkatan kreatifitas anak yang sesuai dengan budaya luhur bangsa Indonesia. Oleh karena itu, maka penelitian ini mengambil judul "Perancangan Level Poin Game Manik Angkeran Berbasis Android Tahap Pertama".

\section{METODE PENELITIAN}

Metode penelitian meliputi analisa permasalahan, arsitektur atau rancangan metode yang digunakan untuk menyelesaikan masalah.

\subsection{Perancangan}

Perancangan adalah penggambaran, perencanaan dan pembuatan sketsa atau pengaturan dari beberapa elemen yang terpisah ke dalam satu kesatuan yang utuh dan berfungsi sebagai perancangan sistem dapat dirancangdalam bentuk bagan alir sistem (system flowchart), yang

JSIKTI Vol. 2, No. 2, Desember 2019: $89-100$ 
merupakan alat bentuk grafik yang dapat digunakan untuk menunjukan urutan-urutan proses dari sistem. Jogiyanto (2005).

Pengertian Perancangan Aplikasi Konsep merancang multimediamerupakan aplikasi multimedia yang akan dibuat. Untuk dapat merancang konsep dalam membuat aplikasi multimediadibutuhkan kreatifitas. Kreatifitas adalah kemampuan untuk menyajikan gagasan atau ide baru. Sedangkan inovasi merupakan aplikasidari gagasan atau ide baru tersebut. Untuk menciptakan ide yang orisinil tidaklah mudah, maka dapat digunakan beberapa teknik untuk menciptakan ide, yaitu penyesuaian (adaptasi), Multimedia yang telah ada dianggap belum sesuai dengan lingkungan yang dituju.

\subsection{Manik Angkeran}

Manik Angkeran terpesona melihat emas, intan, dan permata di hadapannya. Tiba-tiba ada niat jahat yang timbul dalam hatinya. Karena ingin mendapat harta lebih banyak, dengan secepat kilat dipotongnya ekor Naga Besukih ketika Naga berputar kembali ke sarangnya. Manik Angkeran segera melarikan diri dan tidak terkejar oleh Naga. Tetapi karena kesaktian Naga itu, Manik Angkeran terbakar menjadi abu sewaktu jejak-nya dijilat sang Naga. Mendengar kernatian anaknya, kesedihan hati Sidi Mantra tidak terkatakan. Segera dia mengunjungi Naga Besukih dan memohon supaya anaknya dihidupkan kembali. Naga menyanggupinya asal ekornya dapat kembali seperti sediakala. Dengan kesaktiannya, Sidi Mantra dapat memulihkan ekor Naga. Setelah Manik Angkeran dihidupkan, dia minta maaf dan berjanji akan menjadi orang baik. Sidi Mantra tahu bahwa anaknya sudah bertobat tetapi dia juga mengerti bahwa mereka tidak lagi dapat hidup bersama. Dalam sekejap mata dia lenyap. Di tempat dia berdiri timbul sebuah sumber air yang makin lama makin besar sehingga menjadi laut. Dengan tongkatnya, Sidi Mantra membuat garis yang memisahkan dia dengan anaknya. Sekarang tempat itu menjadi selat Bali yang memisahkan pulau Jawa dengan pulau Bali..

\subsection{Desain Komunikasi Visual}

Di Indonesia kegiatan desain dikelompokkan menjadi tiga bagian besar; Desain Produk Industri (Industrial Design), Desain Komunikasi Visual (Visual Communication Design), dan Desain Interior (Interior Design). Dari tiga bagian besar tersebut, pada penelitian ini hanya akan dibahas tentang Desain Komunikasi Visual, yaitu; profesi yang mengkaji dan mempelajari desain dengan berbagai pendekatan dan pertimbangan, baik yang menyangkut komunikasi, media, citra, tanda maupun nilai. Dalam buku berjudul Desain Komunikasi Visual yang ditulis oleh Supriyono, disebutkan bahwa desain komunikasi visual memiliki peran mengkomunikasikan pesan atau informasi kepada pembaca dengan berbagai kekuatan visual, seperti typography, ilustrasi, warna, garis, lay out, dan sebagainya dengan bantuan teknologi (Supriyono, $2010: 9$ ).

Cenadi (1999:4) menjelaskan pengertian desain komunikasi visual sebagai desain yang mengkomunikasikan informasi dan pesan yang ditampilkan secara visual.Desainer komunikasi visual berusaha untuk mempengaruhi sekelompok pengamat. Mereka berusaha agar kebanyakan orang dalam target group (sasaran) tersebut memberikan respon positif kepada pesan visual tersebut. Oleh karena itu desain komunikasi visual harus komunikatif, dapat dikenal, dibaca dan dimengerti oleh target group tersebut.

Peranan Desain Komunikasi Visual Dalam Penyampaian Informasi Dalam perkembangannya selama beberapa abad, Desain Komunikasi Visual menurut Cenadi (1999:4) mempunyai tiga fungsi dasar, yaitu sebagai sarana identifikasi, sebagai sarana informasi dan instruksi, dan yang terakhir sebagai sarana presentasi dan promosi.

A. Desain Komunikasi Visual Sebagai Sarana Identifikasi Fungsi dasar yang utama dari desain komunikasi visual adalah sebagai sarana identifikasi.Identitas seseorang dapat mengatakan tentang siapa orang itu, atau dari mana asalnya. Demikian juga dengan suatu benda, produk ataupun lembaga, jika mempunyai identitas akan dapat mencerminkan 
kualitas produk atau jasa itu dan mudah dikenali, baik oleh baik oleh produsennya maupun konsumennya.

B. Desain Komunikasi Visual Sebagai Sarana Informasi dan Instruksi Sebagai sarana informasi dan instruksi, desain komunikasi visual bertujuan menunjukkan hubungan antara suatu hal dengan hal yang lain dalam petunjuk, arah, posisi dan skala, contohnya peta, diagram, simbol dan penunjuk arah. Informasi akan berguna apabila dikomunikasikan kepada orang yang tepat, pada waktu dan tempat yang tepat, dalam bentuk yang dapat dimengerti, dan dipresentasikan secara logis dan konsisten.

C. Desain Komunikasi Visual Sebagai Sarana Presentasi dan Promosi Tujuan dari desain komunikasi visual sebagai sarana presentasi dan promosi adalah untuk menyampaikan pesan, mendapatkan perhatian (atensi) dari mata (secara visual) dan membuat pesan tersebut dapat diingat; contohnya poster. Penggunaan gambar dan kata-kata yang diperlukan sangat sedikit, mempunyai satu makna dan mengesankan. Umumnya, untuk mencapai tujuan ini, maka gambar dan kata-kata yang digunakan bersifat persuasif dan menarik, karena tujuan akhirnya adalah menjual suatu produk atau jasa.

\section{4 Game}

Game adalah sebuah sistem yang melibatkan pemain dalam sebuah konflik buatan, yang ditentukan oleh aturan, dan menghasilkan hasil yang terukur (Salen dan Zimmerman,2003,96). Game adalah sebuah permainan komputer interaktif yang dikendalikan oleh mikroprosesor(Henry,2010). Game atau dalam bahasa indonesia disebut juga permainan tidaklah sembarang, dimana pada sebuah permainan biasanya terdapat aturan yang harus dipahami dan diikuti oleh penggunanya. Game juga terbagi dalam beberapa jenis game yang berbeda-beda yang masing-masingnya mempunyai ciri khas tersendiri. 2.7.1 Jenis Game Selama bertahun-tahun, game telah terbagi ke dalam banyak genre dan subgenre yang berbeda. Sebuah genre permainan digunakan untuk menggambarkan gaya permainan tersebut. Menurut Rogers $(2010,9)$ berikut merupakan beberapa genre dan subgenre game yang ada :

A. Action, Game yang membutuhkan koordinasi mata dan tangan dalam sebuah permainan.

B. Adventure Permainan dengan gaya petualangan lebih fokus pada pemecahan tekateki, pengumpulan barang, dan manajemen persediaan.

C. Conctruction/Management Game ini mengharuskan pemain untuk membangun dan memperluas sebuah lokasi dengan sumber daya yang terbatas

D. Life Simulation Gaya permainan ini hampir sama dengan Construction/Management , tapi hanya sekedar membangun dan memelihara hubungan dengan bentuk kehidupan buatan didalam permainan tersebut.

E. Music/Rhythm Dalam gaya permainan ini, pemain diharuskan untuk mencocokan irama untuk mendapatkan score.

F. Party Genre ini dirancang secara khusus agar beberapa pemain dapat bermain secara bersamaan. Contohnya : Mario Party and Buzz.

G. Puzzle Genre ini menitik beratkan pada logika dan pola penyelesaian. Contohnya : The Incredible Machine dan Tetris.

H. Sports Genre ini berdasarkan pada kompetisi atletik, walaupun dibuat secara ekstrim maupun tradisional.

I. Strategy Genre game ini lebih kepada pemikiran dan perencanaan melalui cerita sejarah maupun cerita fiktif

J. Vehicle Simulation Genre game ini mengharuskan pemain mengendarai kendaraan, mulai dari mobil sport hingga sebuah kapal luar angkasa. Gaya permainan ini dapat memberikan pengalaman senyata mungkin bagi pemainnya.

\subsection{Pengujian blackbox}

Blackbox Menurut Simarmata (2010, 316), klasifikasi black box testing mencakup 
beberapa pengujian salah satunya adalah pengujian fungsional (functional testing).Pada jenis pengujian ini, perangkat lunak diuji untuk persyaratan fungsional.Pengujian dilakukan dalam bentuk tertulis untuk memeriksa apakah aplikasi berjalan seperti yang diharapkan. Walaupun pengujian fungsional sudah sering dilakukan di bagian akhir dari siklus pengembangan, masingmasing komponen dan proses dapat diuji pada awal pengembangan, bahkan sebelum sistem berfungsi, pengujian ini sudah dapat dilakukan pada seluruh sistem.

Pengujian fungsional meliputi seberapa baik sistem melaksanakan fungsinya, termasuk perintah-perintah pengguna, manipulasi data, pencarian dan proses bisnis, pengguna layar, dan integrasi. Pengujian fungsional juga meliputi permukaan yang jelasdari jenis fungsi-fungsi, serta operasi back-end (seperti keamanan dan bagaimana meningkatkan sistem).Pengujian pada black box berusaha menemukan kesalahan seperti:

1. Fungsi-fungsi yang tidak benar atau hilang

2. Kesalahan interface

3. Kesalahan dalam struktur data atau akses database eksternal

4. Kesalahan kinerja

5. Inisialisasi dan kesalahan terminasi

\section{Perancangan permainan}

Perancangan level poin game Manik Angkeran berbasis android tahap pertama ini dirancang dalam empat tahapan perancangan, yaitu tahapan perancangan desain permainan, tahapan perancangan desain visual, tahapan perancangan level poin dan tahapan perancangan antar muka.

1. Perancangan Desain Permainan Pada Game Manik Angkeran ini, secara garis besarnya karakter Manik Angkeran akan melawan dan mengalahkan banyak musuh/raksasa untuk mendapatkan koin emas (pis bolong mas). Nantinya, koin-koin yang terkumpul akan digunakan untuk membeli bahan baku yang digunakan membangun sebuah asrama (pesraman). Para pengguna game ini wajib mengklik/tap pada layar handphone untuk menggerakkan karakter Manik Angkeran agar dapat mengalahkan musuh-musuhnya yaitu para raksasa. Klik/tap ini dilakukan hingga tenaga dari tiap-tiap musuh mereka habis. Adapun yang menjadi kunci dari desain mekanik game Manik Angkeran ini adalah mengalahkan musuh/raksasa untuk mengumpulkan koin emas (pis bolong mas). Dimana nantinya, koin-koin ini dapat digunakan untuk membeli bahan bangunan, yang akan digunakan untuk membangun asrama (pesraman). Genre / gaya permainan dari game ini adalah termasuk dalam kategori Idle Game. Dimana Idle Game merupakan game yang dibuat hanya untuk dilihat karena semua bentuk permainannya terjadi secara otomatis [3] Untuk berinteraksi dengan

Game genre Idle ini, cenderung hanya melakukan klik/tap pada layar. Hal ini membuat genre ini juga dikenal dengan Tap Game, karena tidak perlu begitu banyak menghapal fungsi tombol-tombol yang berbeda.

2. Perancangan Desain Visual Pada tahapan perancangan Desain Visual ini, dibagi menjadi dua tahapan. Tahapan pertama adalah mengumpulan literasi literasi visual, melakukan riset ilustrasi tokoh untuk memahami dan membentuk tokoh yang dirancang sesuai tujuan yang diharapkan. Tahapan kedua adalah adalah menterjemahkan sketsa gambar ke digital art berdasarkan pola hasil pengembangan atau inovasi. Membuat beberapa gambar sebagai bagian adegan dalam menyusun animasi. Desain karakter untuk tap gameplay terlihat tampak belakang. Namun untuk memperkuat detail karakter, disediakan character design turnaround yang memperlihatkan tampak depan, samping kanan-kiri, 3/4, dan perspective view. Referensi desain karakter mengacu pada sumber gambar pejuang Bali kuno sebelum penjajahan Belanda ke Bali, yang disajikan pada gambar 1 berikut. 


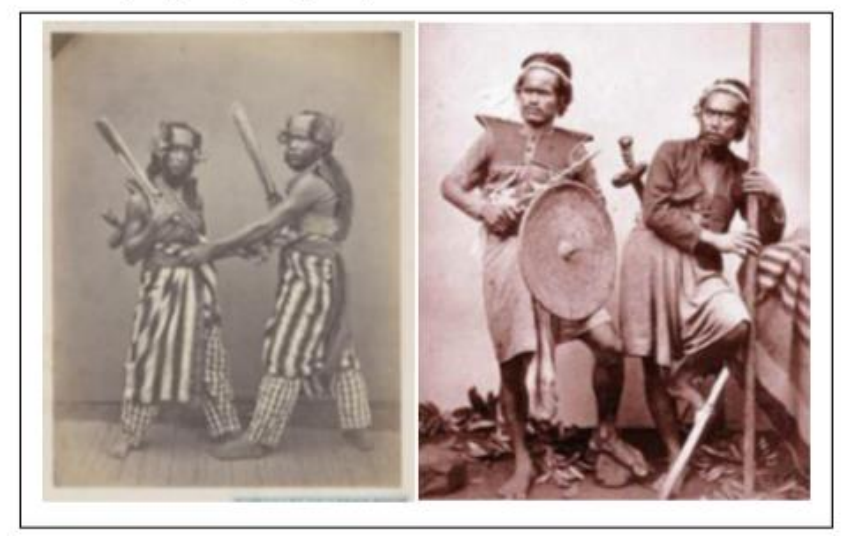

Gambar 1 Gaya lukisan young artist ubud

Gambar 2 merupakan contoh gaya seni yang digunakan untuk gambar latar belakang (backgorund) dari game yang dibuat. Gaya tersebut adalah gaya artistik Young Artist Ubud, yang dikombinasikan dengan gaya realis. Pembuatan aset gambar latar belakang dilakukan dengan menggunakan teknik lukisan digital menggunakan preset kuas cat air.

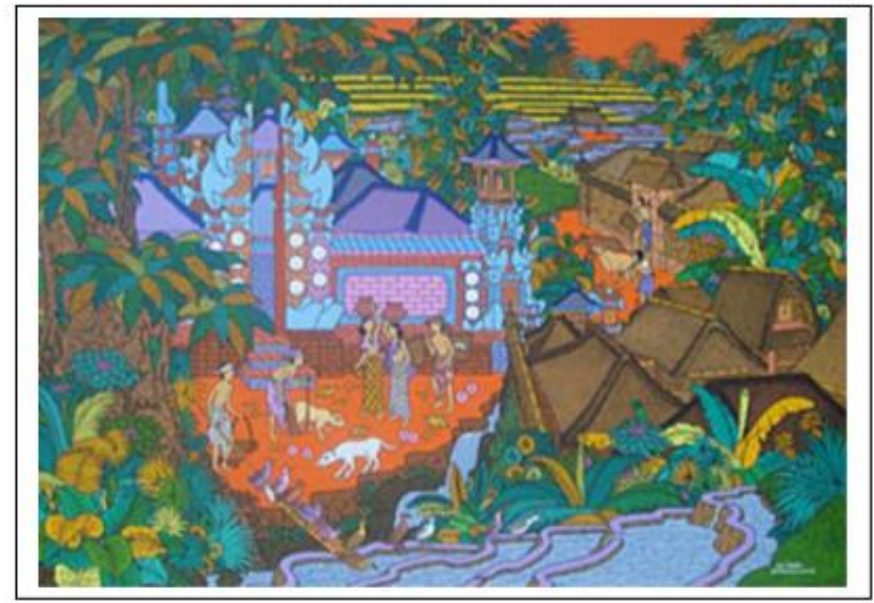

Gambar 2 Gaya lukisan young artist ubud dengan cat air

3. Perancangan Level Poin

Pada tahapan perancangan Level Poin ini, dibagi menjadi dua tahapan. Tahapan pertama adalah perancangan level poin yang meliputi level per level dari Game Manik Angkeran. Dimana pada masing-masing level permainan, karakter Manik Angkeran akan menghadapi musuh-musuh yang berbeda dan harus mengumpulkan koin dengan jumlah tertentu untuk dapat menyelesaikan setiap level permainan. Dan tahapan kedua adalah merancang animasi kharakter Manik Angkeran untuk game android. Pada tahapan perancangan level poin dari game Manik Angkeran ini, dirancang dan ditetapkan beberapa karakter yang terlibat. Karakter-karakter tersebut adalah Karakter Manik Angkeran, Naga Basukih dan beberapa karakter raksasa yang menjadi musuh dari Manik Angkeran.

Gerakan standar yang dimiliki oleh Karakter Manik Angkeran adalah gerakan senjata biasa. Namun, selain itu, pada game ini disediakan 5 kekuatan yang dapat digunakan untuk melawan para musuh/raksasa, yaitu kekuatan Api, Air, Angin, Tanah, dan Ether. Masingmasing kekuatan ini memiliki daya pukul dengan besaran berbeda saat digunakan melawan musuh. Seluruh kekuatan ini memiliki keterbatasan waktu dalam penggunaannya, dimana jika sudah digunakan, kekuatan ini memerlukan waktu untuk pengisian tenaga (charge). Masing-masing kekuatan ini pun akan membuat animasi gerakan dari Manik Angkeran akan bervariatif bergantung dari kekuatan yang digunakan. Dari sisi musuh/raksasa, para 
musuh/raksasa ini memiliki besaran tenaga yang berbeda-beda juga. Indikator besaran tenaga dari musuh/raksasa berada di posisi atas pada layar, dimana setiap terkena pukulan dari Manik Angkeran, indikator tenaga dari para musuh akan berkurang sesuai besaran kekuatan yang Manik Angkeran sedang gunakan.

Jika tenaga musuh habis, maka muncul animasi musuh kalah, yang dilanjutkan dengan animasi mendapatkan hadiah koin. Besaran hadiah koin ini sifatnya diacak, sehingga pemain tidak dapat memprediksi berapa koin yang didapatkan. Setiap koin yang dikumpulkan, nantinya akan digunakan untuk membeli bahan bangunan yang digunakan membangun asrama (pesraman). Berdasarkan perancangan level poin tersebut, pada tahapan kedua, dilakukan perancangan dan penetapan beberapa gerakan animasi pada masingmasing karakter. Adapun beberapa animasi karakter yang akan dibuat adalah animasi karakter dengan beberapa gerakan. Masing-masing gerakan ini dibuat menggunakan metode Animasi Sprite.

Animasi sprite adalah salah satu cara untuk membuat animasi yang serupa dengan teknik animasi tradisional, yaitu dengan menjejerkan secara berurutan setiap gambar gerakan dari sebuah objek atau karakter pada sebuah kanvas dari kiri ke kanan. Urutan sejumlah gambar ini dapat disimpan dalam 1 file, biasanya file berekstensi PNG. File animasi sprite ini berisi sejumlah urutan gerakan karakter sekaligus baik dari gerakan berjalan, berlari, menendang dan memukul. Nantinya, file ini akan dibaca dan diterjemahkan oleh engine bernama Corona SDK, yang menggunakan bahasa pemrograman LUA. Dimana dengan menggunakan engine ini, file animasi sprite akan dibaca, diterjemahkan dan dapat menampilkan masing-masing gerakan dari karakter sesuai dengan keperluan

4. Perancangan Antar Muka Adapun rancangan tampilan antar muka dari game yang dibuat pada penelitian ini adalah terdiri dari Menu Loading, Menu Peta dan Menu Gameplay. Berikut adalah tampilan ketiga menu tersebut,

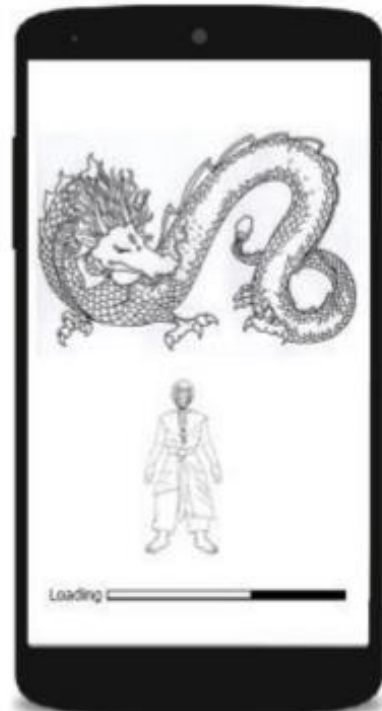

(a)

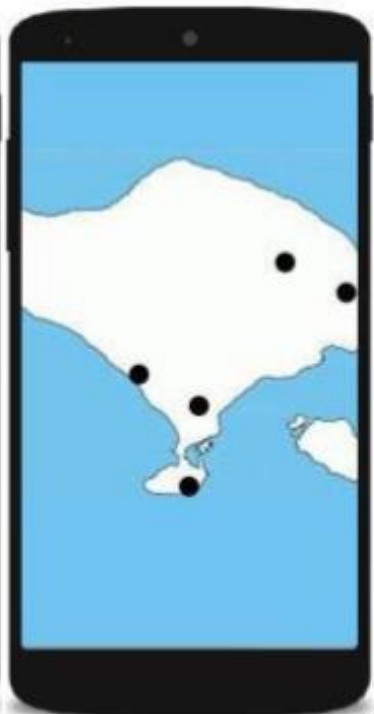

(b)

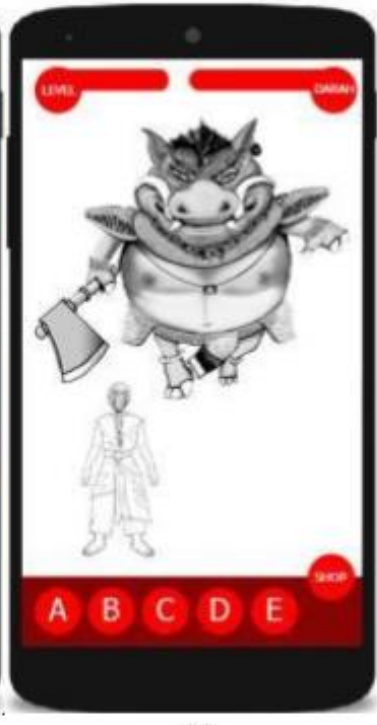

(c)

Gambar 3 Rancangan antarmuka aplikasi

Pada tampilan Menu Loading gambar 3 (a), akan terdapat gambar ilustrasi dari aplikasi yang dibuat dengan gambar ilustrasi dari Naga Basukih dan Manik Angkeran. Menu ini berfungsi tampilan jeda antar menu, dan untuk mempersiapkan tampilan berikutnya yang akan tampil. Pada tampilan ini juga terdapat tulisan Loading dan progress bar yang akan bergerak dari kosong ke penuh (kiri ke kanan) sebagai ilustrasi lama waktu tunggu. Selanjutnya pada gambar 3 (b), merupakan tampilan Menu Peta. Tampilan ini merupakan tampilan berupa Peta Pulau Bali yang berisi 5 (lima) lokasi wisata atau tempat bersejarah di 
Pulau Bali. Tampilan ini berfungsi untuk memilih lokasi mana yanga akan dimainkan atau dituju, sekaligus mengetahui sudah sejauh mana progres permainan dari user.

Pada awal permainan, user harus memulai permainan dari Nusa Dua dahulu, karena 4 lokasi sisanya akan dikunci. Hal ini bertujuan agar user dapat berproses dari lokasi dan level awal, hingga nanti berakhir di Gunung Agung. Tampilan terakhir adalah tampilan Menu Gameplay pada gambar 3 (c). Pada tampilan ini, dibagi menjadi 3 bagian tampilan yaitu bagian atas, tengah dan bawah. Pada bagian atas, terdapat tampilan informasi mengenai level permainan, jumlah koin yang dikumpulkan user, serta informasi sisa darah dari raksasa yang dilawan. Sedangkan pada bagian tengah, merupakan tampilan utama dari game yang akan diisi oleh gambar background dari lokasi yang dipilih atau dimainkan, berikut dengan gambar animasi raksasa beserta dengan gambar Manik Angkeran.

Pada bagian tengah ini juga nantinya akan dimunculkan koin-koin yang akan didapat oleh Manik Angkeran setiap memukul raksasa. Dan terkhir pada tampilan bagian bawah, terdapat 6 (enam) tombol, dimana 5 tombol awal berfungsi sebagai 5 tombol kekuatan khusus (special power) yang akan menampilkan masing-masing jurus berbeda yaitu kekuatan Api, Air, Angin, Tanah, dan Ether. Sedangkan 1 tombol lagi adalah dipersiapkan untuk tampilan Menu Shop atau berbelanja yang akan dilanjutkan pada penelitian selanjutnya.

\section{HASIL DAN PEMBAHASAN}

Pada Bab ini diuraikan tahapan-tahapan penelitian yang dilakukan. Selain itu, juga dipaparkan penerapan skenario pengujian dan melakukan evaluasi dengan menganalisis hasil pengujian yang telah dilakukan. Hasil analisis disajikan pada bagian akhir dari Bab ini.

\subsection{Pembuatan Desain Karakter}

Pada bab ini dipaparkan tahapan-tahapan pembuatan desain karakter dari Manik Angkeran, Raksasa, serta Latar Belakang (background). Adapun proses pembuatan desain karakter ini dibagi menjadi beberapa tahap, yaitu Sketsa Dasar, Pewarnaan, dan proses Penganimasian.

3.1.1 Sketsa Dasar Dalam Sketsa dasar ini, penulis bermaksud mencari persepsi gambar yang sesuai atas Karakter yang diinginkan dalam perancangan, seperti pada Gambar 4 dan 5.
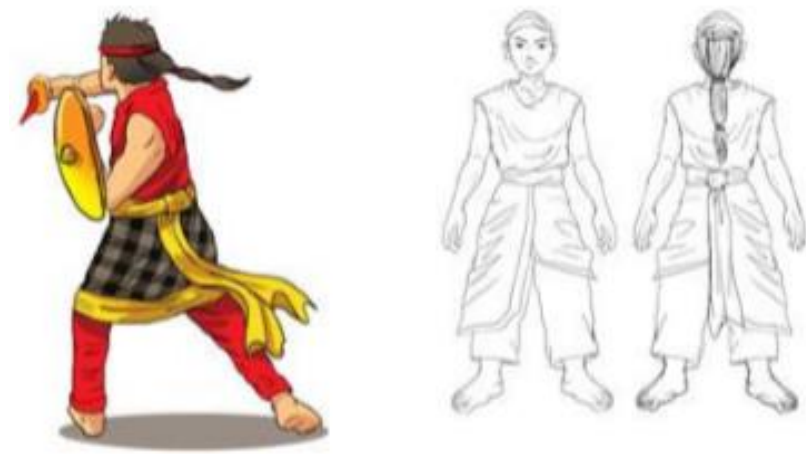

Gambar 4 Karakter Manik Angkera

Dari riset yang dilaksanakan, serta mengumpulkan sumber refrensi yang ada maka, berikutnya dibuat sebuah ide perancangan melalui sketsa yang dilakukan secara manual.Pemahaman yang ada pada karater yang diinginkan adalah sesosok laki laki muda bernama manik angkeran, dengan desain yang berciri khas daerah namun tak lepas dari budaya Bali.

\subsubsection{Penganimasian Karakter}

Proses berikutnya adalah merancang aset untuk dianimasikan. Untuk mempermudah proses animasi, Karakter aset dibuat pada Adobe Ilustrator. Hal ini dilakukan untuk 
mempermudah kombinasi pewarnaan antara Karakter di Adobe Ilustrator dan Karakter setelah di bawa ke Adobe Photoshop. Setelah Karakter jadi ,kemudian disimpan dalam format png. Proses Perancangan Karakter di Adobe Ilustrator Hasil proses pembuatan Karakter berformat png kemudian disempurnakan kembali di Adobe Photoshop. Tujuannya adalah di Adobe Photoshop sangat mudah membuat animasi sederhana. Di dalam Adobe Photoshop, animasi hanya dibuat dalam beberapa gambar pergerakan, sehingga sangat mudah dikelola pada software game dan sangat ringan. Untuk menggerakkan dari gambar gambar tersebut mempergunakan bantuan tool timeline. Untuk penyimpanan dipergunakan extensi psd atau png.
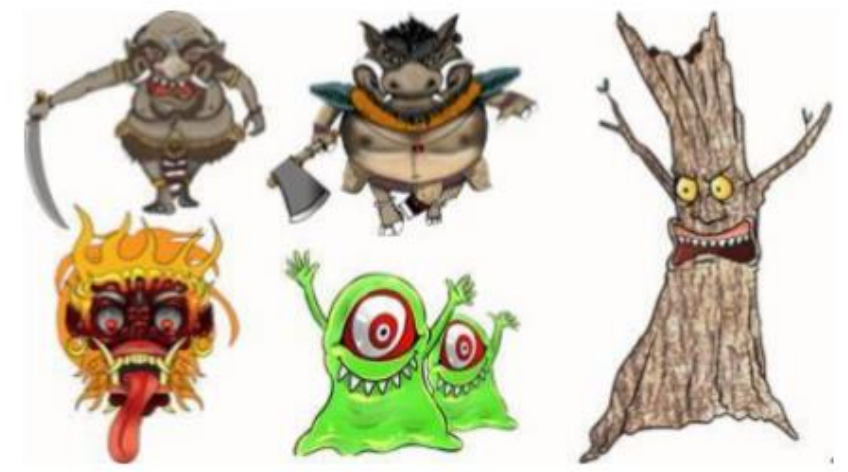

Gambar 5 Karakter raksasa

\subsection{Implementasi Antarmuka}

Pada bagian ini akan dijelaskan realisasi dan implementasi dari perancangan antarmuka sebelumnya menjadi tampilan aplikasi pada perangkat bergerak handphone. Adapun mode tampilan yang digunakan adalah mode Lanskap untuk memudahkan navigasi dari pengguna. Untuk kecepatan penganimasian per detiknya, pada game ini digunakan ukuran 30 frame per detiknya.

\subsubsection{Tampilan Menu Loading}

Pada tampilan halaman Menu Loading ini, terdapat ilustrasi dari karakter Manik Angkeran yang berhadapan dengan Naga Basukih. Fungsi dari tampilan menu ini adalah sebagai tampilan jeda dari satu scene ke scene lainnya.

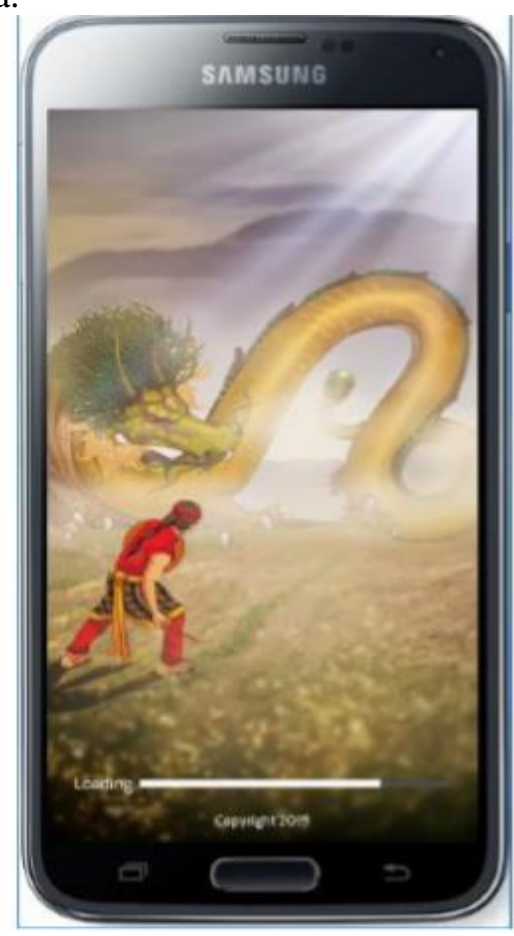

Gambar 6 Menu loading 
Untuk mendukung fungsi tersebut, maka pada tampilan Menu Loading ini berisi tulisan teks "Loading", beserta animasi bar progres pada bagian bawah yang akan bergerak dari kosong ke peneuh atau dari kiri ke kanan, sebagai indikator durasi waktu dari jeda tampilan. Berikut adalah tampilan dari Menu Loading yang terdapat pada gambar 6.

\subsubsection{Tampilan Menu Gameplay}

Pada tampilan Menu Gameplay, merupakan tampilan utama dari game Manik Angkeran ini. Pada tampilan ini, dibagi menjadi 3 bagian tampilan yaitu bagian atas, tengah dan bawah. Pada bagian atas, terdapat tampilan informasi mengenai level permainan, jumlah koin yang dikumpulkan user, serta informasi sisa darah dari raksasa yang dilawan. Sedangkan pada bagian tengah, merupakan tampilan utama dari game yang akan diisi oleh gambar background dari lokasi yang dipilih atau dimainkan, berikut dengan gambar animasi raksasa beserta dengan gambar Manik Angkeran. Pada bagian tengah ini juga nantinya akan dimunculkan koin-koin yang akan didapat oleh Manik Angkeran setiap memukul raksasa. Dan terkhir pada tampilan bagian bawah, terdapat 6 (enam) tombol, dimana 5 tombol awal berfungsi sebagai 5 tombol kekuatan khusus (special power) yang akan menampilkan masing-masing jurus berbeda yaitu kekuatan Api, Air, Angin, Tanah, dan Ether. Sedangkan 1 tombol lagi adalah dipersiapkan untuk tampilan Menu Shop atau berbelanja yang akan dilanjutkan pada penelitian selanjutnya.

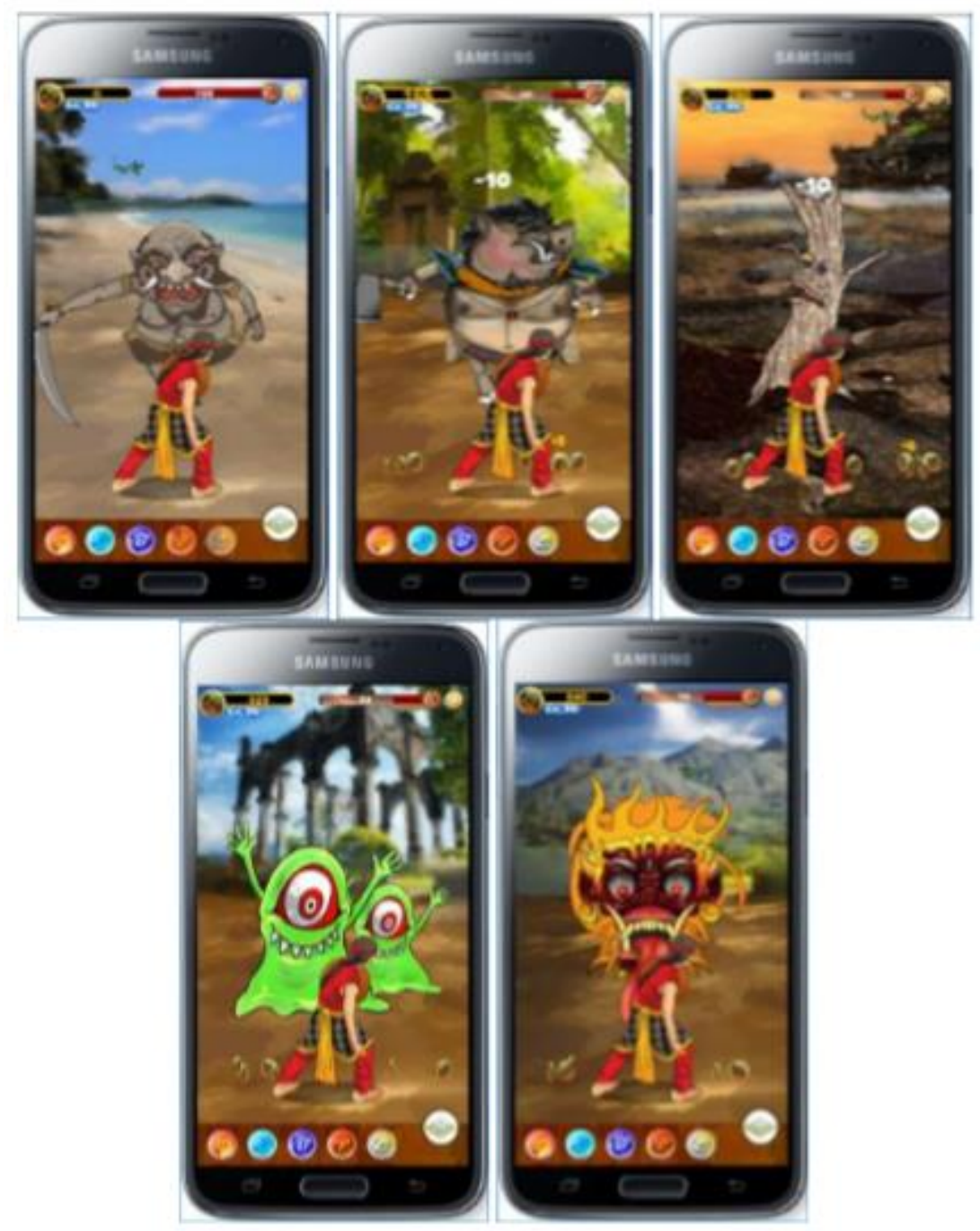

Gambar 6 Tampilan menu game play

JSIKTI Vol. 2, No. 2, Desember 2019: $89-100$ 
Pada tampilan Menu Gameplay ini, user hanya perlu mengetuk (tap) pada bagian tengah dari halaman menu untuk menggerakkan karakter Manik Angkeran dalam mengalahkan para raksasa. Gerakkan memukul dari karakter Manik Angkeran beserta gerakan terkena pukul dari raksasa ditampilkan secara acak sesuai dengan jumlah gerakan masing-masing yang disediakan. Jika user tidak mengetuk layar, maka karakter Manik Angkeran dan raksasa hanya melakukan gerakan siaga (idle). Setiap user mengetuk layar, selain menampilkan animasi gerakkan dari karakter Manik Angkeran dan raksasa, sejumlah koin dan nominalnya akan muncul pada layar. Jumlah dari Koin ini secara otomatis akan ditambahkan pada informasi jumlah koin di bagian kiri atas. Begitu pula dengan jumlah sisa darah dari raksasa, setiap raksasa terkena pukulan, maka akan tampil gerakan animasi raksasa terpukul, berikut nominal nilai pukulannya. Nominal nilai pukulan ini lah yang akan mengurangi bar progres dari darah yang dimiliki oleh raksasa di bagian atas kanan layar. Besaran nominal dari pukulan Manik Angkeran bervariasi bergantung dari jenis pukulan yang digunakan. Jenis pukulan tersebut ada pukulan biasa, dan juga ada 5 jenis jurus pukulan yang dapat ditampilkan setiap user menekan 5 pilihan tombol jurus spesial pada tampilan layar bagian bawah. Gambar 5.10 berikut ini merupakan tampilan dari Menu Gameplay.

\subsection{Pengujian Aplikasi}

Pengujian Aplikasi Skenario pengujian pada penelitian ini menggunakan metode pengujian blackbox testing. Skenario pengujian dapat dilihat pada Tabel 1.

Tabel 1 Skenario dan hasil pengujian blackbox

\begin{tabular}{|c|c|c|c|c|}
\hline No & Skenario Pengujian & $\begin{array}{l}\text { Hasil Yang } \\
\text { Diharapkan }\end{array}$ & $\begin{array}{l}\text { Hasil } \\
\text { Sistem }\end{array}$ & $\begin{array}{c}\text { Keterangan } \\
\text { Gambar }\end{array}$ \\
\hline 1 & Menu Loading & $\begin{array}{l}\text { Menampilkan Menu } \\
\text { Loading dan progres } \\
\text { bar loading berjalan } \\
\text { dari kiri ke kanan }\end{array}$ & Valid & Gambar 5.8 \\
\hline 2 & Menu Peta & $\begin{array}{l}\text { Menampilkan Menu } \\
\text { Peta dan hanya } \\
\text { mengunci lokasi yang } \\
\text { belum dapat diakses. }\end{array}$ & Valid & Gambar 5.9 \\
\hline 3 & $\begin{array}{l}\text { Menu Gameplay : Gerak dari } \\
\text { Manik Angkeran }\end{array}$ & $\begin{array}{l}\text { Menampilkan dan } \\
\text { menggerakkan karakter } \\
\text { Manik Angkeran sesuai } \\
\text { dengan tombol atau } \\
\text { jurus spesial yang } \\
\text { ditekan (pukulan biasa, } \\
\text { jurus spesial Api, Air, } \\
\text { Angin, Tanah, dan } \\
\text { Ether). }\end{array}$ & Valid & Gambar 5.10 \\
\hline 4 & Menu Gameplay : Gerak Musuh & $\begin{array}{l}\text { Menampilkan dan } \\
\text { menggerakkan karakter } \\
\text { musuh sesuai dengan } \\
\text { situasi gerakan } \\
\text { seharusnya (siaga atau } \\
\text { terkena pukul). }\end{array}$ & Valid & Gambar 5.10 \\
\hline
\end{tabular}

\section{KESIMPULAN}

Adapun yang dapat disimpulkan pada penelitian ini adalah sebagai berikut. Perancangan pengembangan level poin game Manik Angkeran berbasis android tahap pertama ini telah 
berhasil dilakukan dengan menggunakan Bahasa Pemrograman LUA. Berdasarkan hasil pengujian, seluruh fungsionalitas dari aplikasi telah berjalan dengan baik, ketajaman tampilan gambar pada perangkat handphone yang digunakan untuk pengujian sesuai dengan yang diharapkan. Hanya saja, pengaruh spesifikasi perangkat sangat mempengaruhi performa dari aplikasi. Semakin tinggi spesifikasi dari perangkat handphone, maka semakin baik pula tampilan serta kecepatan dari perangkat untuk membuat dan menampilkan gambar berukuran besar.

\section{SARAN}

Adapun beberapa hal yang dapat dipertimbangkan dalam pengembangan aplikasi ini antara lain : Memberi menu Setting / Pengaturan untuk mengatur volume suara atau pun tanpa suara, Mengembangkan ke bahasa lainnya seperti Bahasa Bali maupun Bahasa Inggris, dan Memberi cerita serta pesan moral pada aplikasi.

\section{DAFTAR PUSTAKA}

[1] Cenadi, Christine Suharto. 1999. Elemen-elemen dalam Desain Komunikasi Visual. Nirmana Vol. 1, No. 1, Januari 1999: 1-11.

[2] Henry, Samuel. 2010. Cerdas dengan Game : Panduan Praktis bagi Orangtua dalam Mendampingi Anak Bermain Game. Jakarta: Gramedia Pustaka Utama.

[3] Jogiyanto, H.M. 2005. Analisa dan Desain Sistem Informasi: Pendekatan Terstruktur Teori dan Praktik Aplikasi Bisnis. Yogyakarta. ANDI

[4] Rogers, S. 2010. Level Up! The Guide to Great Video Game Design. United Kingdom: John Willey \& Sons.

[5] Rustan, Surianto. 2008. Layout Dasar \& Penerapannya. Jakarta: PT Gramedia Pustaka utama.

[6] Sachari, Agus. 2012. Estetika. Bandung : Penerbit ITB

[7] Salen, K., dan Zimmerman, E. 2003. Rules of Play - Game Design Fundamental. Cambridge : MIT Press.

[8] Senn, James A. 1998. Information Technology In Business : Principles, Practice and Opportunitier. New Jersey : Prentice-Hall International, Inc.

[9] Simarmata, Janner. 2010. Rekayasa Perangkat Lunak. Yogyakarta: ANDI Offset.

[10] Supriyono, Rakhmat. 2010. Desain Komunikasi Visual Teori dan Aplikasi.Yogyakarta : ANDI.

[11] Thwaites, Tony, Lyod Davis, Warwick Mules. 2009. Introducing Cultural and Media Studies:Sebuah Pendekatan Semiotik. Yogyakarta : Jalasutra

[12] Tinarbuko, Sumbo. 2003. Semiotika Analisis Tanda Pada Karya Desain Komunikasi Visual. NIRMANA Vol 5, No 1. Januari $2003: 31-47$

JSIKTI Vol. 2, No. 2, Desember 2019: $89-100$ 